\title{
PENGEMBANGAN MODEL PELATIHAN IPTEKS BAGI KEWIRAUSAHAAN (IbK) UNTUK MENINGKATKAN KEMAMPUAN PENGELOLAAN BISNIS DIKALANGAN MAHASISWA
}

\author{
Nugraha $^{1}$, Reni Amaranti ${ }^{2}$, Aswardi Nasution ${ }^{3}$ \\ Jurusan Teknik Industri, Fakultas Teknik, Universitas Islam Bandung ${ }^{1,2,3)}$ \\ Bandung, Jawa Barat \\ E-mail :nugraha692004@yahoo.com ${ }^{1}$,reniamaranti2709@yahoo.com², \\ aswardinasution@yahoo.com ${ }^{3}$
}

\begin{abstract}
Main discussion of this study is about the need proper entrepreneurship training program in higher education, especially for students, this study aims to acquire as well as to develop a proper entrepreneurial training model to improve ability of business management among students. The approach Model used in this study are ; 1) the development model of training science and technology for Entrepreneurship (IbK) , 2) model of Problem Based Learning (PBL) is one of the training strategy oriented contectual teaching and learning process (CTL). The CTL training concept helps the trainers / instructors / teachers to links materials with real world situations as well as to encourage the participants using their knowledge to be applied in their real life situation the members of society. From the training model implementation results, it can be concluded that: 1) The training model combining The Problem Based Learning (PBL) and the development of science and technology training model for Entrepreneurship (IbK )could be effectively applied in an entrepreneurship training program for higher education level students, 2) This model succesfully synergize the materials / theories of the training to the real world situations ; 3) This model also works to build the teamwork. Finally, this model manage to indicate its effectiveness by the level of attendance at $90 \%$, as well as teamwork formed in making innovative, original and worth-to-be implemented business proposal.
\end{abstract}

Keywords : Science and Technology for Entrepreneurship (IBK), Problem Based Learning (PBL).

\section{PENDAHULUAN}

Seorang wirausaha dapat mengurangi tingkat kebergantungan terhadap orang lain, meningkatkan kepercayaan diri, serta meningkatkan daya beli pelakunya. Selain itu, seorang wirausaha memiliki peran besar dalam perekonomian suatu negara yakni dalam hal menciptakan lapangan kerja, mengurangi pengangguran, hingga menurunkan angka kriminalitas di masyarakat.

Sejalan dengan uraian tentang peran wirausaha di atas, Perguruan Tinggi dalam menghasilkan lulusannya tidak hanya menjadikan sebagai pegawai negeri (PNS), BUMN, pegawai swasta atau pegawai lainnya tetapi berupaya agar lulusannya bisa berwirausaha dan mempunyai peran dalam perekonomian negara dan menuju kemandirian Indonesia. Kondisi kewirausahaan yang ada di Perguruan Tinggi khususnya yang diselenggarakan oleh mahasiswa berjalan kurang efektif karena kurangnya koordinasi dengan Institusi Perguruan Tinggi dan mitra usaha, padahal banyak mahasiswa di lingkungan Fakultas / Program Studi di Perguruan Tinggi mempunyai usaha baik produk / komoditas yang bisa dijual seperti usaha bidang Feisyen, Kuliner, Kerajinan, Periklanan, Desain, Layanan Komputer dan Piranti Lunak. Berdasarkan pengamatan dan penelitian pendahuluan dapat diidentifikasi beberapa permasalahan yang berkaitan dengan potensi, sumber daya dan nilai ekonomi produk mahasiswa.

Tujuan penulisan artikel ini adalah untuk mendapatkan / mengembangkan model pelatihan ipteks bagi kewirausahaan yang sesuai untuk meningkatkan kemampuan pengelolaan bisnis dikalangan mahasiswa. 


\section{KAJIAN LITERATUR}

\subsection{Pendidikan Kewirausahaan}

Kewirausahaan merupakan sesuatu yang berproses (Thoby, 1995) disini proses pembelajaran merupakan bagian yang terpenting dan merupakan kegiatan yang berlanjut terus menerus. Pendidikan kewirausahaan telah diajarkan sebagai disiplin ilmu tersendiri yang independen dengan media pembelajaran berupa pelatihan yang dapat diberikan oleh pihak eksternal maupun dari pengalaman (Yohnson, 2003). Pendidikan kewirausahaan bertujuan membentuk wirausaha yang memiliki kemampuan wirausaha yaitu yang memiliki pengetahuan, keterampilan dan sikap mental wirausaha.

Enam karakteristik sikap mental wirausaha menurut Goffre G.Meredith (dalam Suryana 2001) adalah : percaya diri, berorientasi pada tugas dan hasil, pengambilan risiko, kepemimpinan, keorisinilan dan berorientasi ke masa depan. Sikap mental wirausaha memegang peranan penting, penelitian dari Harvard University menyebutkan bahwa penentu kesuksesan wirausaha $85 \%$ ditentukan oleh sikap mental dan hanya $15 \%$ ditentukan oleh keahlian teknis (Genoveva, 2002).

Hasil studi seorang pakar kewirausahaan Indonesia Sukardi (1991) menyimpulkan adanya sifat - sifat umum wirausaha :

1. Sifat Instrumental, yaitu tanggap terhadap peluang dan kesempatan berusaha maupun yang berkaitan dengan perbaikan kerja.

2. Sifat Prestatif, yaitu selalu berusaha memperbaiki prestasi, mempergunakan umpan balik, menyenangi tantangan dan berupaya agar hasil kerjanya selalu lebih baik dari sebelumnya.

3. Sifat Keluwesan bergaul, yaitu selalu aktif bergaul dengan siapa saja, membina kenalan-kenalan baru dan berusaha menyesuaikan diri dalam berbagai situasi.
4. Sifat Kerja Keras, yaitu berusaha selalu terlibat dalam situasi kerja, tidak mudah menyerah sebelum pekerjaan selesai. Tidak pernah memberi dirinya kesempatan untuk berpangku tangan, mencurahkan perhatian sepenuhnya pada pekerjaan, dan memiliki tenaga untuk terlibat terus menerus dalam kerja.

5. Sifat Keyakinan Diri, yaitu dalam segala kegiatannya penuh optimis bahwa usahanya akan berhasil. Percaya diri dengan bergairah langsung terlibat dalam kegiatan konkrit, jarang terlihat ragu ragu.

6. Sifat Pengambil Resiko yang Diperhitungkan, yaitu tidak khawatir akan menghadapi situasi yang serba tidak pasti dimana usahanya belum tentu membuahkan keberhasilan. Dia berani mengambil resiko kegagalan dan selalu antisipatif terhadap kemungkinankemungkinan kegagalan. Segala tindakannya diperhitungkan secara cermat.

7. Sifat Swa - Kendali, yaitu benar - benar menentukan apa yang harus dilakukan dan bertanggung jawab terhadap dirinya sendiri.

8. Sifat Inovatif, yaitu selalu bekerja keras mencari cara - cara baru untuk memperbaiki kinerjanya. Terbuka untuk gagasan, pandangan, penemuan penemuan baru yang dapat dimanfaatkan untuk meningkatkan kinerjanya. Tidak terpaku pada masa lampau, gagasan gagasan lama, tetapi berpandangan ke depan dan mencari ide - ide baru.

9. Sifat Mandiri, yaitu apa yang dilakukan merupakan tanggung jawab pribadi. Keberhasilan dan kegagalan dikaitkan dengan tindakan - tindakan pribadinya. Dia lebih menyenangi kebebasan dalam mengambil keputusan untuk bertindak dan tidak mau bergantung pada orang lain. 


\subsection{Pelatihan}

Salah satu faktor pendorong kewirausahaan adalah melalui pelatihan kewirausahaan. Pelatihan merupakan aktivitas yang dilakukan untuk meningkatkan pengetahuan, keterampilan dan sikap untuk meningkatkan kinerja saat ini dan masa yang akan datang (Mondy \& Noe dalam Suhartono dan Raharso, 2003). Schuler et.al dalam Yusuf Irianto (1992) dan Anju (2004) merumuskan pelatihan menjadi tiga tahapan integrative yaitu tahap penilaian, tahap implementasi dan tahap evaluasi. Tahap pertama, tahap untuk menentukan kebutuhan apa saja yang harus diakomodasikan dalam pelatihan termasuk bagaimana format dan rancangan pelatihan yang akan diimplementasikan. Tahap kedua, mengimplementasikan semua keputusan tentang pelatihan yang dihasilkan dari tahap pertama. Tahap evaluasi adalah untuk memastikan bahwa pelatihan yang dilaksanakan telah mencapai target yang ditentukan atau sejauh mana efektivitas pelatihan dapat dicapai.

\section{MODEL PELATIHAN KEWIRAUSAHAAN}

\subsection{Desain Model Pendidikan} Kewirausahaan

Desain model pendidikan kewirausahaan adalah melalui Problem Based Learning ( $P B L)$ merupakan salah satu strategi pelatihan yang berorientasi pada contectual teaching and learning process (Jones, Rasmussen dan Moffit, 1997). Contectual Teaching and Learning (CTL) merupakan konsep pelatihan yang membantu pelatih mengaitkan antara materi pelatihan dengan situasi dunia nyata dan mendorong peserta pelatihan untuk menggunakan pengetahuan yang dimilikinya dapat diterapkan dalam kehidupan mereka sebagai anggota masyarakat. PBL adalah pembelajaran yang lebih menekankan pada pemecahan problem autentik yang terjadi sehari - hari (John, 2008:374).
PBL dapat diartikan sebagai pembelajaran berbasis proyek, pendidikan berbasis pengalaman, belajar autentik pembelajaran yang berakar pada masalah masalah kehidupan nyata. Gijbels (2005:29) menyatakan bahwa PBL adalah cara pembelajaran yang bermuara pada proses pelatihan berdasarkan masalah - masalah nyata. Titik berat masalah-masalah nyata dalam proses pembelajaran ini merupakan hal yang paling penting.

Pada pelatihan model PBL tersebut peserta belajar melalui situasi dan setting pada masalah-masalah yang nyata atau kontekstual. Karena itu, semua dijalankan dengan cara-cara :

1. Dinamika kerja kelompok.

2. Investigasi secara independen.

3. Mencapai tingkat pemahaman yang tinggi.

4. Mengembangkan keterampilan individual dan sosial.

Pada model PBL ini berbeda dengan pembelajaran langsung yang menekankan pada prestasi ide - ide dan keterampilan pelatih. Peran pelatih pada model PBL adalah menyajikan masalah, mengajukan pertanyaan dan mempfasilitasi penyelidikan dan dialog. PBL tidak akan terjadi tanpa keterampilan pelatih dalam mengembangkan lingkungan pelatihan yang memungkinkan terjadinya pertukaran ide dan dialog secara terbuka antara pelatih dan peserta pelatihan.

Pelatihan dengan metode PBL harus menggunakan masalah - masalah nyata sehingga peserta pelatihan belajar, berfikir, kritis dan terampil memecahkan masalah dan mendukung pengembangan keterampilan teknis serta perolehan pengetahuan yang mendalam. Pada metode pembelajaran PBL ini memfokuskan pada :

1. Pemecahan masalah nyata.

2. Kerja kelompok.

3. Umpan balik.

4. Diskusi.

5. Laporan akhir. 
Peserta pelatihan didorong untuk lebih aktif terlibat dalam materi pelajaran dan mengembangkan keterampilan berfikir kritis, sehingga peserta berlatih melakukan penyelidikan dan inkuiri. Levin (2001:1) menyatakan bahwa PBL adalah metode pembelajaran yang mendorong peserta pelatihan untuk menerapkan cara berfikir kritis, keterampilan menyelesaikan masalah, dan memperoleh pengetahuan mengenai problem dan isu - isu riil yang dihadapinya. Pada PBL ini pelatih akan lebih berperan sebagai fasilitator atau tutor yang memandu peserta pelatihan menjalani proses pembelajaran.

Adapun langkah - langkah berlatih kewirausahaan dengan metode Problem Based Learning (PBL) adalah sebagai berikut :

a. Peserta pelatihan dibagi dalam kelompokkelompok kecil dan masing - masing kelompok disodori permasalahan bisnis yang nyata (connecting the problem).

b. Masing - masing kelompok diberikan penjelasan tentang tugas dan tanggung jawab (setting the structure) yang harus dilakukan oleh kelompoknya dalam mempelajari permasalahan yang dihadapi.

c. Peserta pelatihan di masing - masing kelompok berusaha maksimal untuk mengidentifikasikan masalah bisnis (visiting the problem) yang diajukan dengan pengetahuan yang dimiliki yaitu : mengidentifikasi masalah dengan seksama untuk menemukan inti problem bisnis yang sedang dihadapi dan mengidentifikasi cara untuk memecahkan masalah bisnis tersebut.

d. Peserta pelatihan di masing - masing kelompok mencari informasi dari berbagai sumber (buku, pedoman dan sumber lain) atau bertanya pada pakar (kader) yang mendampingi untuk mendapatkan pemahaman tentang masalah (re-visiting the problem).

e. Berbekal informasi yang diperoleh peserta kembali ke masing - masing kelompoknya untuk bekerjasama dan berdiskusi dalam memahami masalah dan bertanggung jawab untuk menciptakan solusi (produce the product) yang profesional terhadap masalah dihadapi. Pelatih bertindak sebagai pengamat dan penasehat.

f. Masing - masing kelompok mempresentasikan hasil belajarnya kepada kelompok kecil lainnya untuk disiskusikan dan mendapatkan masukan dan penilaian (evaluation) dari kelompok lainnya.

Adapun prosedur kerja dalam pelaksanaan pembelajaran kewirausahaan dengan metode problem based learning, dapat digambarkan melalui siklus sejak mulai dari penyampaian masalah kepada peserta pelatihan sampai dengan kegiatan evaluasi kinerja yang dicapai mereka sebagai berikut.

\subsubsection{Keunggulan PBL dalam Pelatihan Kewirausahaan.}

Metode PBL digunakan untuk melibatkan peserta pelatihan pada obyek nyata di bidang bisnis secara optimal dalam proses pembelajaran. Keterlibatan fisik, fikiran dan mental peserta ini akan mampu mendorong motivasi belajar, keterampilan mengambil keputusan, dan melatih berfikir kritis dan kerja inovatif dalam memecahkan berbagai masalah bisnis yang dihadapi. Pada metode PBL ini, pertama - tama pelatih menyampaikan masalah bisnis tertentu kepada peserta pelatihan untuk dipelajari. Kemudian, dalam kelompok - kelompok kecil peserta harus mengkaji secara seksama permasalahan tersebut. Selanjutnya peserta melakukan penelitian dengan mencari sumber referensi dan juga observasi di lapangan. Berdasarkan informasi dari hasil Penelitian ini peserta kemudian melakukan diskusi dalam kelompoknya dengan bantuan kader sebagai pendamping. Pada akhirnya peserta akan menemukan penjelasan, solusi atau rekomendasi kelompok terhadap permasalahan yang mereka pelajari. Temuan kelompok selanjutnya didesiminasikan dalam kelas untuk mendapatkan masukan, saran dan penilaian dari kelompok lain dan 
pelatih. Tujuan utama dari metode ini bukan semata - mata untuk menemukan pemecahan masalah, melainkan bertujuan agar peserta pelatihan mempelajari konsep - konsep cara pemecahan masalah dan mengembangkan kemampuan berfikir kritis.

Indikator keberhasilan adalah apabila $75 \%$ siswa mampu berpartisipasi dalam kategori minimal baik (kerja sama tim dalam menyelesaikan tugas, mondorong peserta pelatihan melakukan pengamatan dan dialog dengan orang lain, pembelajaran mandiri) setelah menerapkan Problem Based Learning (PBL).

\subsection{Model Pelatihan Ipteks bagi Kewirausahaan (IbK) untuk Mahasiswa Unisba}

Model pelatihan yang diterapkan pada program Ipteks bagi Kewirausahaan (IbK) untuk mahasiswa yang diselenggarakan di
Universitas Islam Bandung (Unisba) seperti pada gambar 1 .

Tahap pertama adalah Pra Pelatihan yaitu proses rekruitmen dan seleksi calon peserta pelatihan yaitu mahasiswa, kemudian perencanaan bidang usaha yaitu bidang peminatan calon peserta pelatihan meliputi tiga bidang yaitu :

1. Industri kreatif bidang kuliner.

2. Industri kreatif bidang IT dan piranti lunak.

3. Industri kreatif bidang Fesyen.

Tahap kedua adalah pelaksanaan pelatihan meliputi pengetahuan / materi tentang kewirausahaan, pengelolaan bisnis, membuat proposal usaha (business plan), serta kunjungan lapangan. Tahap ketiga adalah pasca pelatihan meliputi bimbingan dan klinik usaha, serta monitoring dan evaluasi.

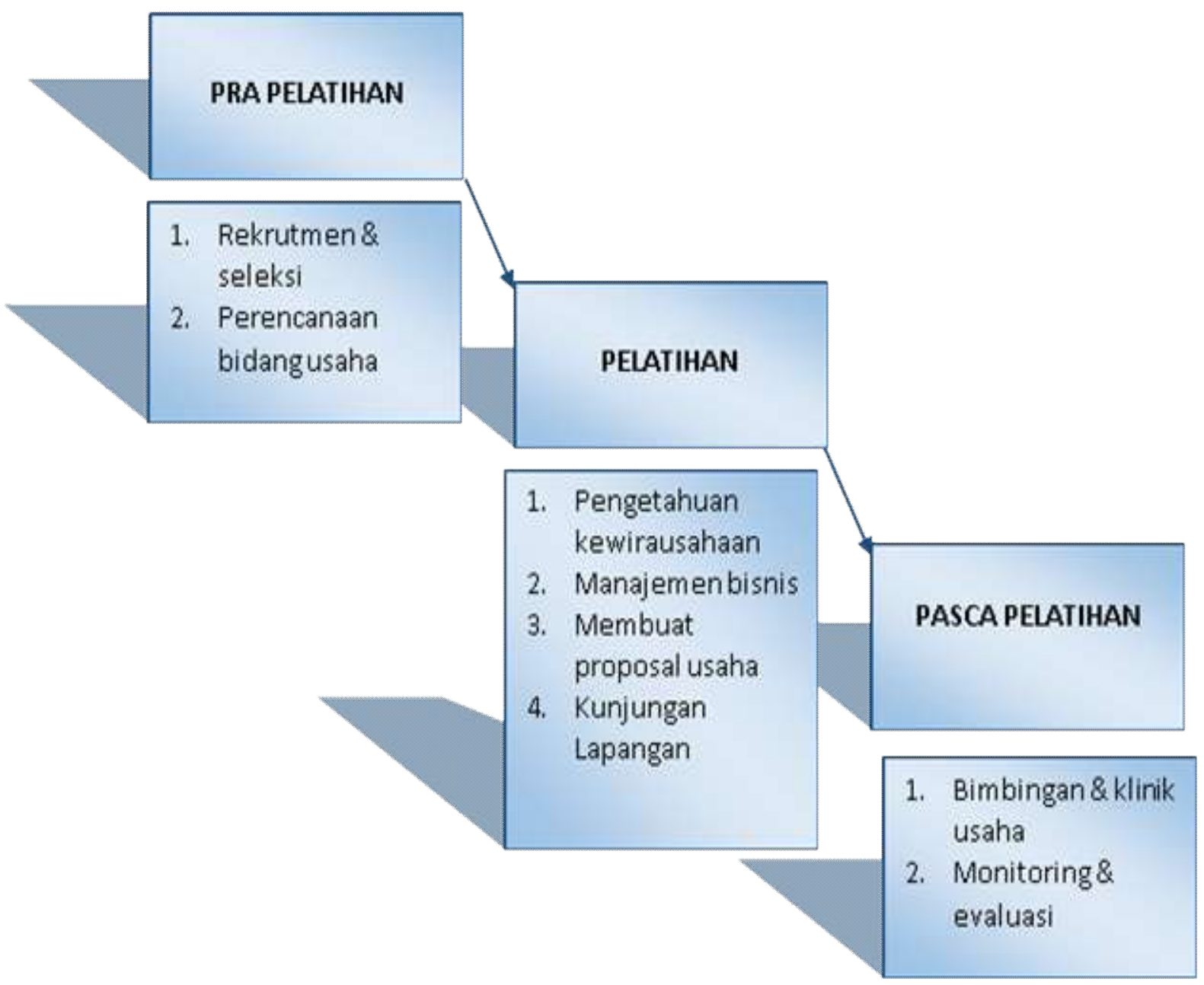

Gambar 1. Konsep Model Pelatihan Kewirausahaan Program IbK. 
Indikator keberhasilan adalah apabila $80 \%$ siswa mampu berpartisipasi dalam kategori minimal baik (kerjasama tim, melakukan pengamatan dan dialog dengan orang lain, pembelajaran mandiri) setelah menerapkan program Ipteks bagi Kewirausahaan (IbK).

\section{PEMBAHASAN}

Pelaksanaan program IbK untuk mahasiswa di Unisba telah berjalan dua (2) tahun dari program tiga (3) tahun,dengan tema "Meningkatkan Kemampuan Pengelolaan Bisnis Dalam Rangka Menciptakan Wirausaha Mandiri,,.

Pelaksanaan pelatihan tahun pertama dibagi tiga yaitu :

1. Materi yang meliputi Manajemen wirausaha, manajemen organisasi bisnis, manajemen produksi, manajemen pemasaran, pengelolaan administrasi keuangan, online marketing, teknik membuat proposal, communication skill, legal aspek / perizinan, analisis kelayakan usaha, cara merintis bisnis ICT industri kreatif, ritel manajemen, teknik membuat proposal.

2. Kunjungan Lapangan yaitu ke Cimahi Community College untuk industri kreatif bidang piranti lunak berbasis teknologi informasi, rumah makan Ampera dan perusahaan kue Inacookies untuk industri kreatif bidang kerajinan dan kuliner, idustri kerajinan kulit untuk industri kreatif bidang feisyen.

3. Presentasi pembuatan proposal untuk masing - masing individu peserta pelatihan.

Dari tujuan, jenis pelatihan dan pelaksanaan kegiatan pelatihan berdasarkan hasil evaluasi di lapangan dan pembagian kuesioner ada beberapa hal yang perlu dipertahan dan yang diperbaiki, untuk evaluasi perbaikan yaitu :
1. Materi yang disampaikan terlalu banyak sehingga perlu pemadatan materi sehingga peserta tidak terlalu jenuh dalam menerima materi didukung dengan modul pelatihan.

2. Cara penyampaian materi yang komunikatif sehingga akan memberikan kenyamanan bagi peserta pelatihan.

3. Tempat pelatihan tidak hanya didalam kampus tetapi bisa diluar kampus yang akan menimbulkan kenyamanan dan suasana yang baru dan segar.

4. Adanya alat peraga / praktek dalam pelatihan.

5. Pembuatan proposal dan presentasi sebaiknya tidak personil tetapi berkelompok.

6. Dari point ke -5 diperlukan tim building untuk menjaga kekompakan kelompok dan rasa tanggung jawab.

7. Tempat kunjungan perusahaan sebaiknya perusahaan yang mempunyai konsep yang sudah memadukan pemasaran konvesional serta modern (online marketing).

Dari uraian hasil evaluasi tersebut maka untuk tahun kedua, model yang digunakan adalah model pengembangan pelatihan Ipteks bagi Kewirausahaan (IbK) untuk mahasiswa Unisba serta model Problem Based Learning (PBL) merupakan salah satu strategi pelatihan yang berorientasi pada contectual teaching and learning process (CTL) merupakan konsep pelatihan yang membantu pelatih / instruktur / pengajar, mengaitkan antara materi pelatihan dengan situasi dunia nyata dan mendorong peserta pelatihan untuk menggunakan pengetahuan yang dimilikinya dapat diterapkan dalam kehidupan mereka sebagai anggota masyarakat. 
Pelaksanaan pelatihan tahun ke - 2 yaitu sebagai berikut :

1. Materi yang diberikan secara garis besar meliputi aspek pemasaran, aspek keuangan, aspek organisasi dan manajemen, aspek produksi, aspek keuangan, materi penunjang lainnya yaitu kemampuan berkomunikasi serta presentasi (comunication skil) bagi setiap individu dan kelompok, teknik membuat proposal bisnis, perizinan / legal aspek.

2. Pembentukan kelompok bisnis, dari 20 peserta pelatihan dibagi menjadi 5 kelompok yang dibentuk sejak awal pertemuan pertama, dengan kelompok ini diharapkan ada beberapa hal penting, yaitu :

a. Diskusi kelompok untuk menentukan produk yang akan dibuat dalam Business Plan.

b. Ketua kelompok berperan sebagai moderator untuk memimpin diskusi.

c. Satu orang bertugas mencatat hasil diskusi.

d. Diskusi dimulai dengan perkenalan, penyampaian pendapat disampaikan secara berurutan dan hasilnya dicatat.

e. Hasil akhir diskusi ( Menentukan bidang usaha : fashion / kuliner / IT, Menentukan produk (unik, kreatif, mampu untuk dibuat sampel dan dilakukan tes pasar).

3. Adanya kegiatan tim building untuk menjaga kekompakan / kerjasama kelompok, pembentukan mental, siap dalam mengatasi segala permasalahan.

4. Kunjungan lapangan yaitu untuk mengetahui kegiatan langsung di perusahaan / wirausaha.

5. Pembimbingan / pendampingan wirausaha yang dijalankan oleh 5 kelompok yang sudah terbentuk.
6. Presentasi hasil aktivitas kewirausahaan, baik dalam pembuatan proposal bisnis, pelaksanaan kewirausahaan. Dari penerapan kedua model yaitu PBL dan IbK terlihat indikator kerberhasilan dari tingkat kehadiran mencapai $90 \%$ dari mulai pembukaan sampai penutupan hanya 2 orang yang tidak hadir, kerjasama tim dengan pembuatan proposal rencana usaha yang inovasi, orisinal serta layak untuk di implementasikan.

\section{KESIMPULAN DAN SARAN}

Dari hasil penerapan pelatihan terhadap model yang diuraikan diatas dapat disimpulkan bahwa :

1. Model pelatihan dengan menggabungkan model Problem Based Learning (PBL) dan model pengembangan pelatihan Ipteks bagi Kewirausahaan (IbK) untuk mahasiswa Unisba merupakan model yang bisa diterapkan dalam kegiatan pelatihan kewirausahaan.

2. Mensinergikan antara materi / teori pelatihan dengan situasi dunia usaha / nyata.

3. Kerjasama secara teamwork terbentuk. Disarankan perlunya keterlibatan dengan dinas terkait serta proporsi kunjungan lapangan yang lebih banyak. Dari penerapan kedua model yaitu PBL dan IbK terlihat indikator kerberhasilan dari tingkat kehadiran mencapai 90\%, kerjasama tim dengan pembuatan proposal rencana usaha yang inovasi, orisinal serta layak untuk di implementasikan. 


\section{DAFTAR PUSTAKA}

Genoveva,"Mengenal Lebih Dekat: Kewirausahaan", Jurnal Ekonomi Perusahaan, Jakarta, STIE IIBI, 2002.

Gijbels, D, Dochy, F dan Van de Bossche,F. Effects of The Problem Based Learning. A Meta-analysis from the Angle Measurement. Journal Review of Educational Research. Vol.75, 27-49. 2005.

Jones, B.F., Rasmussen, C.M., \& Moffitt, M.C. "Real Life problem solving: A collaborative approach to interdisciplinary learning". Washington, DC : American Psychological Association, 1997.

Levin, B. (Ed.).Energizing Teacher Education And Professional Development With Problem-Based Learning. Alexandria, VA: Association for Supervision and Curriculum Development, 2001.

Meredith, Geofrey,G. et.all.. The Practice of Entrepreneurship. Geneva: International Labour Organization, 2002.

Mondy \& Noe, Human Resources Management, 6 ed, New York: Prentice hall Inc, 1996.

Suryana, Kewirausahaan, Jakarta, Salemba Empat, 2001.

Torp, Linda dan Sage Sara Problem as Possibilities, Problem Based Learning for K-16. USA: Association for Supervision and Curriculum Development, 2002.

Yohnson, "Peranan Universitas Dalam Memotivasi Sarjana Menjadi Young Entepreneurs", Jurnal Manajemen dan Kewirausahaan, , Universitas Kristen Petra, Surabaya, Vol 5 No.2 September 2003. 